ANDRZEJ KASPEREK

Uniwersytet Śląsi

w Katowicach

\title{
SŁOWIAŃSZCZYZNA W PODRĘCZNIKACH. STUDIUM SOCJOLOGICZNE NAD MOŻLIWOŚCIĄ BUDOWANIA ALTERNATYWNYCH NARRACJI HISTORYCZNYCH O POCZĄTKACH PAŃSTWA POLSKIEGO
}

\begin{abstract}
Kasperek Andrzej, Stowiańszczyzna w podręcznikach. Studium socjologiczne nad możliwościq budowania alternatywnych narracji historycznych o początkach państwa polskiego [Slavism in Coursebooks. A Sociological Study Into the Possibility of Building Alternative Historical Narrations on the Beginning of the Polish State]. Studia Edukacyjne nr 43, 2017, Poznań 2017, pp. 315-334. Adam Mickiewicz University Press. ISSN 1233-6688. DOI: 10.14746/ se.2017.43.19

What has been undertaken in this study is the problem of narrations, alternative to the predominant historical discourse, about the beginning of Polish statehood. The considerations on the existence of such narrations are situated in the perspective "dominant culture - counterculture". Some references are made to the research concerning the presentation in history course books and curricula of two events in the history of Poland: the christening of Mieszko I and the so called pagan reaction. What is suggested here is enriching the research conclusions with the issues of Romantic "revelation" and introducing Slavism into the $19^{\text {th }}$ century culture as well as viewing the early state of the Piast dynasty in the Ciril-Methodius tradition. The author formulates the thesis that in the analysed coursebooks and curricula the narration about the early Polish statehood is subordinated to the evolutionaryrevolutionary model of interpreting history.
\end{abstract}

Key words: Slavism, counterculture, history, memory sites, textbooks, curricula, baptism of Poland, pagan reaction

\section{Wprowadzenie}

Maria Janion w książce Niesamowita Stowiańszczyzna postawiła pytanie, czy humanistyka (zasadniczo chodziłoby o tę uprawianą przez Polaków) 
„chce i może (...) stworzyć alternatywną opowieść"1, która opierałaby się na wyrwaniu polskiej narracji z zaklętego kręgu niższości-wyższości? Niższości wobec łacińskiego Zachodu, rekompensowanej mesjanistyczno-martyrologicznym poczuciem wyższości wobec „niemoralnego" Zachodu, wyższości okraszonej przekonaniem o historycznej roli, jaką Polska ma odgrywać w misji cywilizowania Wschodu. Książkę Janion można potraktować jako próbę „snucia” takiej alternatywnej opowieści, przy czym kluczową rolę odgrywa w niej narracja o słowiańszczyźnie budowana z pozycji kontrkultury (w szerszym oczywiście tego słowa znaczeniu niż w znaczeniu kontrkultury młodzieżowej). Niesamowita Słowiańszczyzna jest zarazem studium polskiej „mentalności postkolonialnej”, świadomej własnej peryferyjności, a zarazem karmiącej się oparami mitu o własnej wyjątkowości.

Szansa na stworzenie alternatywnej opowieści (narracji) o dziejach Polski i jej miejscu w Europie (wyznaczanej przez oś podziału na Zachód i Wschód) zakłada zatem z jednej strony rehabilitację samej słowiańszczyzny, rozumianej jako kontrkultura, a z drugiej uświadomienie sobie arbitralności podziału na zachodnią i wschodnią część Europy, arbitralności zakładającej wyższość cywilizacyjną tej pierwszej wobec drugiej. Można studium Janion potraktować jako demaskację kluczowych pojęć stosowanych do określania tożsamości współczesnych Polaków, a mianowicie pojęć "Zachód”, „Wschód" oraz „Europa”. Oczywiście, Maria Janion nie jest tutaj pierwsza, podążając za intelektualną tradycją takiej demaskacji praktykowanej między innymi przez Edwarda W. Saida, czy Karola Modzelewskiego. Celem poniższych rozważań jest natomiast skierowanie dyskusji nad tymi kategoriami w stronę podręcznikowej narracji o kluczowych wydarzeniach z najwcześniejszych dziejów państwa polskiego. Chcę postawić pytanie odnośnie możliwości snucia narracji alternatywnej wobec dominującej, szkolnej wykładni o początkach państwa polskiego. Problematykę tę podjąłem już w opublikowanym, wspólnie z Agatą Cabałą, artykule: The Forgotten Slavism. A Sociological Study on the Depreciation of the Memory Concerning the Slavic Heritage in History Textbooks and Curricula in Secondary Schools², choć wówczas zagadnienia tego nie podejmowaliśmy w perspektywie relacji kultura dominująca - kontrkultura.

${ }^{1}$ M. Janion, Niesamowita Stowiańszczyzna: fantazmaty literatury, Kraków 2006, s. 11.

2 A. Kasperek, A. Cabała, The Forgotten Slavism. A Sociological Study on the Depreciation of the Memory Concerning the Slavic Heritage in History Textbooks and Curricula in Secondary Schools, Kultura i Edukacja, 2013, 5(98), s. 2017-220. 
Interesowała nas narracja o dwóch wydarzeniach z najwcześniejszych faz istnienia państwa polskiego w podręcznikach szkolnych oraz programach nauczania historii - narracja o przyjęciu chrztu przez Mieszka I oraz o tzw. reakcji pogańskiej. Nasz artykuł stanowił przykład studium dyskursu publicznego, którego częścią jest dyskurs elit symbolicznych (np. dyskurs akademicki, artystyczny, kościelny). Szczególną uwagę zwróciliśmy wówczas na problematykę ideologii, gdyż jest ona jednym z elementów analizy dyskursu publicznego. Ideologie są istotnym zasobem kulturowym,

względnie płynnymi zasobami interpretacji, czyli dostarczanymi przez kulturę repertuarami kategoryzacji, symboli i argumentacji, które uzyskują konkretny sens tylko wówczas, gdy zostają w określonej sytuacji zastosowane („uruchomione”) oraz odpowiednio dopasowane do sytuacji ${ }^{3}$.

Zasób ten tworzą zatem najczęściej pojawiające się argumenty, swoista frazeologia i retoryka, charakterystyczne obrazy i symbole pojawiające się w dyskursie elit symbolicznych. W naszym artykule próbowaliśmy odtworzyć charakterystyczne dla podręcznikowego dyskursu zasoby interpretacyjne, które zostają uruchomione $\mathrm{w}$ związku z prezentowaniem wspomnianych dwóch wydarzeń, traktowanych przez nas jako przykłady miejsc pamięci ${ }^{4}$. W poniższych rozważaniach chcę po pierwsze doprecyzować zastosowany wtedy przez nas aparat konceptualny, a po drugie - pokusić się o próbę zaproponowania alternatywnej narracji o wspomnianych dwóch wydarzeniach z dziejów Polski na podstawie tradycji cyrylo-metodiańskiej, ujętej w perspektywie relacji kultura dominująca - kontrkultura.

Cele, jakie stawiam $\mathrm{w}$ niniejszym studium są dwojakiego rodzaju. Po pierwsze, chcę przedstawić krytyczne stanowisko (można je także określić mianem socjologicznej demaskacji) odnośnie uprawiania samej historii przez profesjonalnych historyków, traktowanych tutaj jako najważniejsze ogniwa procesu wytwarzania i przekazywania oraz utrwalania pamięci historycznej. Nośnikiem tej pamięci, będącej jednym z rodzajów pamięci zbiorowej, jest grupa zawodowych historyków ${ }^{5}$.

${ }^{3}$ M. Czyżewski, Wprowadzenie, [w:] Rytualny chaos. Studium dyskursu publicznego, red. M. Czyżewski, S. Kowalski, A. Piotrowski, Kraków 1997, s. 25.

${ }^{4}$ Badaniem objęliśmy łącznie 25 podręczników i 12 programów nauczania historii dla uczniów szkół gimnazjalnych i ponadgimnazjalnych, które ukazały się w latach 1989-2009, a do analizy ostatecznie zakwalifikowano 74 jednostki tekstowe (w tym 37 fragmentów odnoszących się do chrztu Polski oraz 37 fragmentów odnoszących się do tzw. reakcji pogańskiej).

${ }^{5}$ A. Szpociński, Formy przeszłości a komunikacja społeczna, [w:] A. Szpociński, P.T. Kwiatkowski, Przesztość jako przedmiot przekazu, Warszawa 2006, s. 28. 
Znaczenie dyskursu historycznego (...) nie sprowadza się do jego funkcji poznawczej, spełnia on także funkcję społeczną (...). Nie istnieje taki dyskurs historyczny, którego znaczenie byłoby wyłącznie poznawcze ${ }^{6}$.

Interesuje mnie więc także problem prawomocności historii rozumianej jako dyscyplina akademicka.

Po drugie, szczególną uwagę chciałbym zwrócić na praktyczne konsekwencje takiego demaskatorskiego ujmowania historii i jej nauczania w szkole tak dla historyków, jak i szerzej - dla pedagogów czy socjologów. Jedną z konkluzji, jaką chciałbym sformułować na podstawie przeprowadzonych analiz podręczników i programów nauczania historii, jest teza o bezkrytycznym przyjmowaniu przez autorów podręczników modelu spencerowsko-marksowskiego (ewolucyjno-rewolucyjnego) w nauczaniu historii o początkach państwa polskiego ${ }^{7}$. Efektem tej bezkrytyczności, a zarazem dominacji takiego modelu jest opieranie historycznego dyskursu na przekonaniu o nieuchronności i bezalternatywności procesu historycznego. Demaskacja aprioryczności modelu ewolucyjno-rewolucyjnego, związana $\mathrm{z}$ upowszechnieniem krytycznego spojrzenia na dominujący dyskurs historyczny o korzeniach polskiej państwowości, stanowi zatem zachętę do uprawiania "historii krytycznej” w odróżnieniu od "historii brązowniczej” 8 . Jednocześnie powinna ona mieć swoje praktyczne konsekwencje w zmianie sposobu konstruowania programów nauczania historii oraz podręcznikowego dyskursu o początkach polskiej państwowości. Świadomość uwikłania pamięci o przeszłości w kontekst relacji kultura dominująca - kultura(y) zdominowana(e) stanowi wyzwanie dla nauczania historii w szkole. Dyskurs o początkach polskiej państwowości, będąc wpisanym w model ewolucyjny, uwikłany jest jednocześnie w schemat myślenia w kategoriach rozwój - zacofanie, a wszelkie odstępstwa od jednokierunkowości rozwoju traktowane są jako regres. Krytyka modelu ewolucyjnego jest zarazem apologią modelu nauczania historii, w którym akcentuje się wielokierunkowość (alternatywność) zmian, próbując jednocześnie do minimum ograniczać myślenie $w$ kategoriach rozwój (postęp) - zacofanie. $Z$ drugiej strony chciałbym także zwrócić uwagę na zjawisko mitologizacji (w znaczeniu sakralizacji) dyskursu o przyjęciu chrztu przez Mieszka I. Krytyczne spojrzenie na to wydarzenie $\mathrm{w}$ perspektywie relacji chrześcijaństwo - słowiańszczyzna oraz

${ }^{6}$ C. Pereyra i in., Po co nam historia? przekł. M. Mróz, Warszawa 1985, s. 18.

$7 \mathrm{Na}$ temat modeli spencerowskiego i marksowskiego zob. P. Burke, Historia $i$ teoria społeczna, przekł. M. Łamacz, Warszawa - Kraków 2000, s. 164-174.

8 C. Pereyra, Po co nam historia? s. 51-52. 
łacińska i cyrylo-metodiańska tradycja chrześcijańska pozwala na problematyzację i desakralizację tego dyskursu.

\section{Pamięć zbiorowa a historia}

Z perspektywy poniższych rozważań ważne jest wprowadzenie rozgraniczenia między pojęciami „pamięć zbiorowa" i "historia”, co wiąże się ze wskazaniem na socjologiczną i historyczną specyfikę badania przeszłości. Podejmowanie kwestii słowiańskiego dziedzictwa należy rozpatrywać w perspektywie pamięci przeszłości, przy czym socjologiczna i historyczna rekonstrukcja przeszłości spełniają inne funkcje, a zarazem obydwa podejścia wykazują istotne rozbieżności w wyobrażeniach na temat badania przeszłości. Jeśli chodzi o socjologiczną perspektywę, to klasyczne ujęcie problematyki pamięci zbiorowej przypisuje się zwyczajowo Maurice Halbwachsowi, jednakże zostało ono wypracowane na gruncie francuskiej szkoły socjologicznej (szkoły durkheimowskiej) i wkład w jego opracowanie należałoby przypisać także innym reprezentantom tej szkoły (jak np. Henri Hubert, Emil Durkheim, czy Stefan Czarnowski) ${ }^{9}$. Jak zauważają badacze problematyki pamięci zbiorowej (np. Barbara Szacka, Robert Traba, czy Jan Assmann), w twórczości autora Społecznych ram pamięci spotykamy się z odróżnieniem pojęć pamięci zbiorowej od historii. Zarazem jednak Halbwachs nie precyzuje, jakie znaczenia miałyby się wiązać z tymi pojęciami, co niestety pozostaje problemem aż po dzień dzisiejszy. Barbara Szacka charakteryzując współczesny stan badań nad pamięcią zbiorową, zwraca uwagę na problemy związane już z samym nazewnictwem stosowanym do badań nad przeszłością:

(...) jedni mówią o pamięci zbiorowej, inni o społecznej, kulturowej bądź historycznej, jeszcze inni opowiadają się za mówieniem nie o "pamięci”, ale "pamiętaniu”, niektórzy zaś posługują się określeniem „świadomość historyczna”. Pojęcia te są wypełniane różnymi treściami. Co więcej, pojawia się ostatnio szerokie rozumienie pamięci zbiorowej, włączające w jej obręb historię - dyscyplinę akademicką ${ }^{10}$.

9 Jak zauważa jednak Jacek Nowak, problematyka pamięci zbiorowej została po raz pierwszy w klarowny sposób postawiona przez Hugo von Hofmannsthala w 1902 roku. Równocześnie z Halbwachsem nad tym zagadnieniem pracowali Maurice Bloch, Frederic Bertlett, czy Abraham Warburg, Nowak zauważa jednocześnie, że „ślady” badań nad pamięcią na gruncie nauk społecznych znaleźć można między innymi w twórczości Georga Simmla, Karola Marksa, Maxa Webera, czy Edwarda Shilsa (J. Nowak, Społeczne reguty pamiętania. Antropologia pamięci zbiorowej, Kraków 2011, s. 31).

${ }^{10}$ B. Szacka, Czas przeszty, pamięć, mit, Warszawa 2006, s. 18. 
Istnieje także tendencja odwrotna, w której problematyka pamięci zbiorowej zostaje włączona po prostu $\mathrm{w}$ zakres pojęcia historii11.

Problematyka konstruowania obrazu przeszłości w podręcznikach szkolnych, stanowiąca przedmiot mojego zainteresowania, kieruje uwage przede wszystkim $\mathrm{w}$ stronę pojęcia historii, rozumianej jako dyscyplina akademicka, choć ze względu na wzajemne relacje w polu uwagi pozostaje jednocześnie pojęcie pamięci zbiorowej. Bardzo wyraźnie te dwa pojęcia odróżnia od siebie Pierre Nora, który co prawda przeciwstawia sobie pojęcia historii i pamięci, niemniej $\mathrm{w}$ tym drugim przypadku chodzi bez wątpienia o pamięć zbiorową. Nora zwraca uwagę na to, że pojęcia historii i pamięci nie tylko nie są synonimami, ale wręcz stały się we współczesnym społeczeństwie parą opozycyjnych wobec siebie pojęć12. Pamięć, jak pisze, odnosi się do teraźniejszości danego społeczeństwa, natomiast historia - do jego przeszłości i stanowi rekonstrukcję tego co już nie istnieje, przy czym rekonstrukcja jest zawsze problematyczna i niekompletna. Pamięć zawiera w sobie magiczną aurę, historia jako produkt intelektualny jest na wskroś świeckim przedsięwzięciem. Jeśli chodzi o czas, to pamięć istnieje $\mathrm{w}$ czasie wiecznego "teraz", historia natomiast w czasie linearnym ${ }^{13}$. Andrzej Szpociński zwraca uwagę na trzy kryteria odróżniania pamięci zbiorowej (społecznej) od historii: 1) funkcjonalne, 2) strukturalne oraz 3) poznawcze ${ }^{14}$, a jednocześnie kładzie nacisk na odmienny język, którym operują historia (język analityczny, sprawozdawczy) i pamięć zbiorowa (język poetycki, metaforyczny). W przypadku kryterium funkcjonalnego chodzi o różne motywy, dla których zwracamy się $\mathrm{w}$ stronę przeszłości: $\mathrm{w}$ przypadku historii dotyczy to bezinteresowności, zaś w pamięci zbiorowej praktycznych celów (legitymizacja porządku społecznego). Kryterium strukturalne wiąże się z odmiennymi koncepcjami czasu: historia opiera się na czasie linearnym, pamięć zbiorowa porusza w czasie cyklicznym (resp. mitycznym). Kryterium poznawcze wreszcie polega na traktowaniu historii jako czynności gromadzenia prawdziwej wiedzy o przeszłości, pamięci zbiorowej jako uwikłanej $\mathrm{w}$ grupowe interesy i wartości przypisuje się status wiedzy ułomnej ${ }^{15}$.

Wymienione przez Szpocińskiego kryteria należy jednak traktować w kategoriach typów idealnych. W rzeczywistości spotykamy się raczej z różnymi stopniami wzajemnego przenikania się historii i pamięci zbioro-

\footnotetext{
11 Tamże, s. 19.

12 P. Nora, Between Memory and History: Les Lieux de Mémoire, Representations, 1989, 26, s. 8.

13 Tamże, s. 8-9.

${ }^{14}$ A. Szpociński, Formy przeszłości a komunikacja społeczna, s. 19.

15 Tamże.
} 
wej bądź, jak rzecz ujmuje Robert Traba, pamięć i historia wchodzą ze sobą $\mathrm{w}$ relację dialektyczną ${ }^{16}$. Konsekwencją takiej dialektyki jest zbliżenie się socjologicznej (skupionej na badaniu pamięci zbiorowej) i historycznej perspektywy badania przeszłości. Traba podejmując kwestię pożytków socjologicznej perspektywy badania pamięci zbiorowej dla historyków, pisze:

Historyk, zajmując się pamięcią społeczną (nawet jeżeli określa ją innymi, mniej precyzyjnymi kategoriami), może czerpać z bogatego dorobku metodologicznego socjologów, wprowadzając własne pytania badawcze, które wzbogacają kategorie socjologiczne, dając możliwość budowania interesującej siatki pojęciowo-analitycznej, uwzględniającej dynamikę procesów długiego trwania"17.

Za jednego z pionierów uprawiania historii, w którym umiejętnie połączono historyczną i socjologiczną perspektywę badania przeszłości, należy bez wątpienia uznać autora koncepcji „długiego trwania” - Fernanda Braudela.

Jak pisał Braudel, dialog prowadzony z socjologami (wymienia nazwiska reprezentantów francuskiej szkoły socjologicznej: François Simianda, Marcela Maussa, Maurice Halbwachsa) „okazuje się owocny”, choć nie oznacza zgody ${ }^{18}$. Braudel był kontynuatorem, zainaugurowanego w latach dwudziestych ubiegłego wieku we Francji nowego sposobu uprawiania historii, polegającego na przełamaniu monopolu historii politycznej na rzecz historii społecznej, historii obejmującej „wszelkie przejawy ludzkiej działalności” i zajmującej się "analizą 'struktur', a nie relacjonowaniem zdarzeń"19. To nowe spojrzenie na przeszłość zyskało swój instytucjonalny wymiar w chwili powołania w 1929 roku przez Marca Blocha i Luciena Febvre'a czasopisma „Annales d'Histoire Économique et Sociale”, którego współredaktorem (obok Febvre'a) po śmierci Blocha zostaje Braudel, by po śmierci Febvre'a objąć kierownictwo tegoż czasopisma ${ }^{20}$. Charakterystycznym rysem uprawiania historii przez badaczy skupionych wokół "Annales” było zerwanie z tradycyjnym sposobem myślenia o przeszłości jako czymś już nieistniejącym i martwym. „Zdolność pojmowania tego, co żywe - oto w istocie naczelna cnota historyka" 21 . Taka perspektywa niewątpliwie czyniła bliższym

${ }^{16}$ R. Traba, Historia - przestrzeń dialogu, Warszawa 2006, s. 34.

17 Tamże, s. 36.

${ }^{18}$ F. Braudel, Historia i trwanie, przekł. B. Geremek, Warszawa 1971, s. 127.

19 P. Burke, Historia i teoria społeczna, s. 26-27.

20 B. Geremek, W. Kula, Przedmowa, [w:] F. Braudel, Historia i trwanie, s. 6-7.

${ }^{21}$ M. Bloch, Pochwała historii czyli o zawodzie historyka, przekł. W. Jedlicka, Warszawa 1960, s. 68-69. 
środowisku historyków socjologiczną perspektywę badania przeszłości przez pryzmat teraźniejszości ( $\mathrm{w}$ takiej perspektywie należy przecież umieszczać pojęcie pamięci zbiorowej). Związki między historykami i socjologami zostały poniekąd zinstytucjonalizowane, skoro $\mathrm{w}$ komitecie redakcyjnym "Annales" zasiadał Maurice Halbwachs ${ }^{22}$. Marc Bloch przyznawał się do tego, że wywodzi się ze szkoły durkheimowskiej (Marcel Mauss wręcz uważał go za jej przedstawiciela23), a Fernand Braudel tworzył koncepcję "długiego trwania”, wchodząc w dialog z durkheimistami24. Te dwie perspektywy badania przeszłości (socjologiczna i historyczna, zinstytucjonalizowane w postaci czasopism „L'Année Sociologique" i „Annales") pokazały w pewnej mierze arbitralność i sztuczność podziałów, choć oczywiście każda z nich zachowała swoją specyfikę. To zbliżenie pokazało, że historycy mogą wykorzystywać w swoich badaniach socjologiczne kategorie (np. pamięci zbiorowej), a socjologowie historyczne, jak stało się to na przykład z pojęciem les lieux de mémoire („miejsca pamięci”) opracowanym przez Pierre'a Norrę, kontynuatora szkoły „Annales”, w którego pracach można jednocześnie dostrzec wyraźne inspiracje socjologią Halbwachsa ${ }^{25}$. Miejscami pamięci mogą być zarówno geograficznie zdefiniowane miejsca, obiekty, jak i symbole czy wydarzenia z dziejów pewnej zbiorowości. Jak zauważa jednocześnie Nora, miejsca pamięci powstające w wyniku gry między pamięcią i historią mają trzy znaczenia (aspekty): materialne, symboliczne i funkcjonalne ${ }^{26}$. Kiedy Nora pisze o podręczniku szkolnym zauważa, że nawet tak czysto funkcjonalne miejsce może stać się miejscem pamięci, jeśli stanie się przedmiotem rytuału. Analizowane przeze mnie i Agatę Cabałę wydarzenia z historii początków polskiej państwowości, podobnie jak sam podręcznik, można traktować jako miejsca pamięci ${ }^{27}$, a omawiane $\mathrm{w}$ poprzednim rozdziale analizy ogniskowały się właśnie wokół pojęcia les lieux de mémoire.

22 P. Burke, Historia i teoria społeczna, s. 29.

${ }^{23}$ T. Banaszczyk, Durkheim i protagoniśsi, Katowice 1996, s. 88-89.

${ }^{24}$ Ważną rolę w Braudela koncepcji uprawiania historii odegrał Georges Gurvitch, z którym prowadził dysputę. Gurvitch wyróżniał osiem rodzajów czasu społecznego, między innymi czas długiego trwania oraz spowolniony (le temps de longue durée et au ralenti) (zob. G. Gurvitch, La multiplicité des temps sociaux, [w:] G. Gurvitch, La vocation actuelle de la sociologie. Antécédents et perspectives, t. II, Paris 1969, s. 325-430).

25 J. Nowak, Społeczne reguty pamiętania, s. 40.

26 P. Nora, Between Memory and History, s. 18-19.

27 „Zwrot 'miejsce pamięci' dość wiernie oddaje funkcje pełnione przez nazwy zdarzeń, które w świadomości członków określonej grupy społecznej uznane zostały za ważne. Idzie o to (...) że takie nazwy spełniają jak gdyby rolę miejsca, w którym można odnajdywać coraz to nowe wartości, idee, wzory zachowań (...)" (A. Szpociński, Przemiany obrazu przeszłości Polski. Analiza stuchowisk historycznych dla szkót podstawowych 1951 - 1984, Warszawa 1989, s. 19). 
Instytucja szkoły w procesie transmisji pamięci historycznej odgrywa we współczesnych społeczeństwach rolę centralną, zwłaszcza w perspektywie procesu ujednolicania pamięci. Podczas lekcji historii przede wszystkim, na podstawie narzędzi dydaktycznych, którym jest podręcznik, uczniowie poznają kanon historyczny, przez który Andrzej Szpociński rozumie po prostu zbiór miejsc pamięci ${ }^{28}$. Szpociński zauważa, że analizę pamięci o przeszłości można poprowadzić $\mathrm{w}$ trzech wymiarach: przodków, kanonu historycznego (wydarzenia, postaci z przeszłości, o których powinno się coś wiedzieć) oraz wartości, idei i wzorów zachowań. Na potrzeby artykułu The Forgotten Slavism... przyjęliśmy węższą perspektywę analizy przeszłości, która obejmowała analizę kanonu historycznego (tylko pośrednio, w odniesieniu do kanonu także dwa pozostałe wymiary). Ani treści podręcznika, ani kanonu historycznego nie należy jednak traktować jako wolnych od pozanaukowych uwarunkowań. Na taki a nie inny przekaz pamięci o przeszłości wpływ ma państwo zawiadujące systemem oświaty, ale też innymi narzędziami kształtowania obrazu przeszłości (sfera kultury, jak muzea, prasa, ale i rozmaite organizacje). Jak pisze Barbara Szacka odwołując się do tezy postawionej przez Jamesa V. Wertscha: „Państwo (...) jest zainteresowane nie tylko tym, aby jego obywatele znali oficjalną wersję historii, ale aby $\mathrm{w}$ nią wierzyli $(. . .)^{\prime 2}$. Socjologiczny namysł nad historią jako dyscypliną akademicką czerpie także inspirację z Pochwaty historii Blocha, który pyta o rację istnienia historii (prawomocność historii) ${ }^{30}$. Należy bowiem odróżniać intelektualną prawomocność historii od jej użyteczności31. Bowiem, historia obok mitu - jak pisze Luis Villoro - stanowi tę formę kultury, która jest najczęściej wykorzystywana do legitymizacji instytucji, wierzeń, czy celów łączących grupy ${ }^{32}$.

\section{Wokół problematyki alternatywnych narracji historycznych}

Kwestię istnienia alternatywnej opowieści o dziejach (także tych najwcześniejszych) polskiej państwowości postawioną przez Janion można więc rozpatrywać $\mathrm{w}$ kategoriach kontrkulturowego dyskursu, skoro historia jest częścią kultury wykorzystywaną do legitymizacji najważniejszych insty-

28 Tamże.

${ }^{29}$ B. Szacka, Czas przeszty, pamięć, mit, s. 56.

${ }^{30}$ M. Bloch, Pochwała historii, s. 27.

${ }^{31}$ C. Pereyra, Po co nam historia? s. 17.

32 L. Villoro, O sensie istnienia historii, przekł. Maria Mróz, [w:] Po co nam historia, Warszawa 1985, s. 38 . 
tucji oraz zdefiniowanych przez dominujące elity celów grupy. Opozycję pojęciową kultura dominująca - kontrkultura, w której chrześcijańskiemu uniwersum symbolicznemu wspieranemu przez historię (rozumianą jako dyscyplina naukowa) przeciwstawiona zostaje "pogańska”, niechrześcijańska i słowiańska kontrkultura, poddana deprecjonującemu przekazowi i pozbawiona legitymizacji najważniejszych instytucji społecznych, warto zastosować do analizy podręczników i programów. Historia pełni w tym przypadku funkcję nie tyle opisu przeszłości zgodnie z arystotelesowską definicją prawdy jako adaequatio intellectus et rei, ile uzasadnia polityczne i kulturowo-cywilizacyjne wybory pierwszych Piastów. Fundamenty takiej alternatywnej opowieści, mającej romantyczne korzenie, zostały sformułowane przez Zoriana Dołęgę Chodakowskiego 33 na początku XIX wieku w rozprawie O Stawiańszczyźnie przed chrześsijaństwem. Chodakowski pisał:

Zniknęły przed wiedzą uczoną dzieje, obrzędy i zwyczaje nasze w epoce wielobóstwa. Nie sprzyjała oświata Europy całemu czasowi, w którym Krzyż święty wznosić się począł wśród rozległej i podzielonej Sławiańszczyzny. Pierwsi posłańcy do nas z wiarą dzisiejszą dalecy byli od umiarkowania, ażeby mieli co oszczędzić dla historii i wieków, i ten nieprzychylny zapał w ich następcach ledwo do naszych czasów nie doszedł. W tym duchu dziesięciu lub więcej władców naszego plemienia kolejno wywracali budowę przyrodzonym natchnieniem wzniesioną i obok nowych prawideł nieba nie zdołali zabezpieczyć własności ziemskiej, która by przetrwała do nas i była ichże samych pamiątką (...). Czas przyszły wyjaśni tę prawdę, że od wczesnego polania nas wodą zaczęły się zmywać wszystkie cechy nas znamionujące, osłabiał $\mathrm{w}$ wielu naszych stronach duch niepodległy i kształcąc się na wzór obcy, staliśmy się na koniec sobie samym cudzymi ${ }^{34}$.

Fragment to wyborny, zawierający w sobie de facto to, co najważniejsze dla dwudziestowiecznej krytyki kolonializmu i charakterystyki postkolonialnej mentalności. Zorian Dołęga Chodakowski w lapidarny, acz jak dosadny, sposób prezentuje związki między historią i edukacją, szuka przyczyn "zapominania” i „niepamięci” o zbiorowej przeszłości. W takim ujęciu kultura staje się dialektyką pamięci i zapominania, przy czym zapominanie ma charakter nieprzypadkowy i jak najbardziej wybiórczy. Słowianie zostali pozbawieni swojego kulturowego dziedzictwa, uznając za swoje to, co obce. Passus ten, w którym znajdujemy opis procesu kulturowej alienacji, jest de facto antycypacją tego sposobu myślenia, który w dwudziestym wieku legnie u podłoża antykolonialnego dyskursu.

33 Jego prawdziwe imię i nazwisko to Adam Czarnocki.

34 Z. Dołęga Chodakowski, O Stawiańszczyźnie przed chrześcijaństwem, [w:] Z. Dołęga Chodakowski, O Stawiańszczyźnie przed chrześsijaństwem oraz inne pisma i listy, oprac. J. Maślanka, Warszawa 1967, s. 19. 
Równie dosadny cytat możemy znaleźć w pracy opublikowanej w 1807 roku (a więc dwanaście lat przed Zorianem Dołęgą Chodakowskim) przez Wawrzyńca Surowieckiego:

Przyjąwszy chrzest od Rzymian i Greków, przyjęliśmy zarazem ich ducha pogardy i nienawiści do wszystkiego, co było starym lub obcym; ze wstrętem tylko przyzwyczajano nas patrzeć na stan dawny, wystawiano go zawsze w najohydniejszych obrazach. Przy takowym uprzedzeniu Słowianie w pogaństwie musieli nam się wydawać dziką tłuszczą, nie znającą żadnych prawideł obyczajowości i porządku³5.

Analizując podręczniki pisaliśmy o dyskursie deprecjacji (discourse of depreciation), w który wpisana jest podręcznikowa narracja o słowiańszczyźnie ${ }^{36}$. Inspirowaliśmy się tutaj twórczością Axela Honnetha i jego koncepcją społeczeństwa pogardy (société du mépris). Axel Honneth, przeciwstawiając sobie kategorie społecznej pogardy (le mépris) i uznania (la reconnaissance), zwraca uwagę, że praktyki uznania prowadzą do wzrostu podporządkowania jednostek kosztem ich autonomii, a zarazem stają się instrumentem polityki symbolicznej, której funkcją jest integracja jednostek i grup jako podporządkowanych oraz konstruowanie ich pozytywnego wizerunku ${ }^{37}$. Choć zastąpiliśmy Honnetha kategorię pogardy (Surowiecki pisze o duchu pogardy) łagodniejszym terminem deprecjacji, nie mieliśmy wątpliwości, że analizę podręczników warto prowadzić w kategoriach zbliżonych do zaproponowanych przez Honnetha (pogarda vs uznanie). Cytując jeszcze raz Zoriana Dołęgi Chodakowskiego passus „kształcąc się na wzór obcy, staliśmy się na koniec sobie samym cudzymi", nie sposób nie zauważyć, że ceną uznania (także ze strony tych "obcych", czyli chrześcijan) było zapoznawanie pogańskiej słowiańszczyzny, a zarazem przyjęcie statusu "młodszego” partnera, jeszcze niedojrzałego i dopiero wchodzącego w krąg cywilizacji zachodniej. Ceną uznania była więc aprobata własnej niższości.

Myślenie w kategoriach pogardy i uznania realizowało się jeszcze w jeden sposób, który w artykule The Forgotten Slavism... nie stanowił przedmiotu naszego zainteresowania. Chodzi mianowicie o przeniesienie optyki myślenia w kategoriach opozycji: pogarda - uznanie, wyższość - niższość, rozwój - zacofanie na grunt samego chrześcijaństwa i jego podziału na ła-

35 Cyt. za J. Maślanka, Wstęp, [w:] Z. Dołęga Chodakowski, O Stawiańszczyźnie przed chrześcijaństwem, s. 9.

36 A. Kasperek, A. Cabała, The Forgotten Slavism, s. 211.

37 A. Honneth, La société du mépris. Vers une nouvelle Théorie critique, trad. O. Voirol, P. Rusch, A. Dupeyrix, Paris 2006, s. 245. 
cińską i grecką (później cyrylo-metodiańską) tradycję, a co za tym idzie podział Europy na część zachodnią i wschodnią. O ile w przypadku relacji chrześcijaństwo - pogańska słowiańszczyzna kierunkiem aspiracji było to pierwsze, o tyle $\mathrm{w}$ drugim to łacińska tradycja stawała się punktem odniesienia. Co istotne, to właśnie tutaj kryją się możliwości snucia postulowanej przez Marię Janion całkiem realnej alternatywnej narracji (opowieści wykraczającej poza poziom mitu czy poetyckiej wizji, jak często miało to miejsce w przypadku sięgania po dziedzictwo pogańskiej słowiańszczyzny), która mogłaby wyrwać Polaków z kręgu niższości-wyższości. O ile romantyczna apologia pogańskiej słowiańszczyzny z politycznej, ale i kulturowej perspektywy nie jest $\mathrm{w}$ stanie zbyt wiele zaoferować - i tutaj trudno nie zgodzić się z dominującym $\mathrm{w}$ podręcznikach i programach dyskursem, wedle którego chrześcijaństwo było dla powstającego państwa Mieszka I nie tylko szansą na cywilizacyjny rozwój, ale wręcz jego przyjęcie stawało się condicio sine qua non przetrwania - o tyle przyjęcie chrześcijaństwa w łacińskim a nie greckim obrządku wcale za tak bezalternatywne uznawane być nie musi. Co ważne w perspektywie snucia alternatywnych opowieści, to znaczenie języka Słowian, którego wartość nie tyko przecież dla chrześcijańskiej liturgii dostrzegli pochodzący z Tesalonik bracia Cyryl i Metody, opracowując dla Słowian głagolicę. Trudno bowiem snuć jakąkolwiek opowieść bez języka, a jego znaczenie wzrasta wraz z możliwością jego zapisu.

Choć, jak już wspomniałem, w artykule The Forgotten Slavism... nie zajmowaliśmy się problematyką relacji między łacińską i grecką (później cyrylo-metodiańską) tradycją, to w naszych analizach interesowała nas kwestia reakcji pogańskiej. Pisaliśmy, że w podręcznikowym dyskursie ten religijny wymiar buntu został w znacznej mierze stępiony, a sam bunt sprowadzony de facto do zbrojnego wystąienia biednych przeciwko bogatym, tym samym przedstawiony jako coś w rodzaju antycypacji dziewiętnastowiecznej rabacji galicyjskiej. W analizowanych podręcznikach pojawiała się postać Masława (Miecława), który w okresie reakcji pogańskiej sprawował władzę na Mazowszu i następnie długo opierał się wojskom Kazimierza Odnowiciela. W analizowanych podręcznikach także w przypadku buntu Masława jego religijny charakter (powrót do pogańskiej słowiańszczyzny) był marginalizowany i przedstawiany w kategoriach walki o władzę. Skądinąd dobrze jednak znamy ten antychrześcijański wymiar buntu Masława - Józef Ignacy Kraszewski w swojej książce Mastaw: powieść z XI wieku na opozycji chrześcijaństwo Kazimierza Odnowiciela i pogaństwo Masława zbudował oś swojej narracji. 
Istnieje jednak i alternatywna interpretacja postaci Masława, wedle której jego zbrojne wystąpienie miało charakter religijny, tyle że miałoby okazać się wystąpieniem w obronie słowiańskiego obrządku w ramach chrześcijaństwa. Problem jest w rzeczywistości jeszcze szerszy, bo dotyczy dyskusji na temat obecności na terytorium państwa Mieszka I cyrylo-metodiańskiej tradycji. Można bowiem postawić tezę, że Mieszko I wcale nie schrystianizował ludności państwa, którym rządził, lecz raczej je zlatynizował, przyjmując po raz drugi chrzest, tyle że w obrządku łacińskim. Ta alternatywna opowieść o początkach państwa polskiego także ma - jak wyraźnie zaznacza Maria Janion - romantyczne korzenie i była szeroko dyskutowana w latach czterdziestych dziewiętnastego wieku za sprawą poglądów Wacława Aleksandra Maciejowskiego, jednak znajduje i protagonistów wśród dwudziestowiecznych badaczy historii, np. w osobach Henryka Paszkiewicza, Franka Kmietowicza, Zbigniewa Dobrzyńskiego, Józefa Umińskiego, czy w końcu Jerzego Klingera ${ }^{38}$. Określanie Masława mianem poganina miałoby zatem inny charakter, bo chodziłoby de facto o stygmatyzację wschodniej tradycji chrześcijaństwa i było efektem dominującej narracji zwycięskiej łacińskiej tradycji. Co jednak warte podkreślenia, w postaci Masława jak w soczewce skupia się kontrkulturowy, skazany na zapomnienie charakter słowiańskiego dziedzictwa. W obu przypadkach (czy to jako obrońcy pogańskiej słowiańszczyzny, czy jako protagonisty wschodniego obrządku chrześcijańskiego) postać Masława należałoby potraktować jako broniącą słowiańszczyzny w jej autentyczności (czy w wierzeniach, czy w języku liturgii), jako obrońcę tego co autentyczne $\mathrm{w}$ kulturze, jako tę, która - cytując jeszcze raz Zoriana Dołęgę Chodakowskiego - kontestowała zewnętrzne i obce wpływy, które musiały zaprowadzić do sytuacji, gdzie "staliśmy się na koniec sobie samym cudzymi". Co jednak ważne, w obu przypadkach Masław byłby rzecznikiem wypartych i skazanych na zapomnienie tradycji, traktowanym bądź jako poganin, bądź jako innowierca.

Podręcznikowa narracja o chrzcie Polski oraz o pogańskiej reakcji została wpisana w dyskurs rozwój - zacofanie. Autorzy podręczników przyjmują niejako a priori ewolucyjny model interpretacji historii - model, który można ująć także w inną parę opozycyjnych pojęć, silnie naznaczonych kulturową opresją: cywilizacja - barbarzyństwo. Jak pisze Karol Modzelewski, myślenie w takich kategoriach przejął po Grekach, a później Rzymianach Kościół doby późnego cesarstwa, nadając tej opozycji nowe znaczenie: chrystianizowanie pogańskich ludów staje się od tej pory misją cywilizacyjną ${ }^{39}$. Maria

${ }^{38}$ M. Janion, Niesamowita stowiańszczyzna, s. 98-102.

${ }^{39}$ K. Modzelewski, Barbarzyńska Europa, Warszawa 2004, s. 10. 
Janion zwraca natomiast uwagę, że ta starożytna opozycja pojęć cywilizacji i barbarzyństwa przeradza się w nowożytnym świecie $\mathrm{w}$ opozycję Zachodu i Wschodu, gdzie Wschód staje się synonimem zacofania ${ }^{40}$. Wschód i Zachód należy oczywiście traktować jako konstrukty intelektualne, poprzez które manifestują się „stosunki siły, dominacji, złożonej hegemonii o różnym nasileniu (...)"41. Oczywiście, Saida interesował bardziej Bliski czy Daleki Wschód, relacje kulturowego imperializmu, w perspektywie których spogląda na relacje Wschód - Zachód odnoszące się jednak bez wątpienia do relacji Europa Zachodnia - Europa Wschodnia. Najpierw słowiańszczyzna, potem tradycja cyrylo-metodiańska z perspektywy zlatynizowanej Europy Zachodniej doświadczą na sobie kulturowego imperializmu Zachodu. Co jednak istotne, Saida interesował też wątek oporu kulturowego, będącego odpowiedzią na zachodni kulturowy imperializm.

Narracja jest również metodą, za pomocą której ludy skolonizowane potwierdzają własną tożsamość i istnienie własnej historii ${ }^{42}$. I dalej: Moc snucia opowieści, lub też blokowania innych opowieści, jest czynnikiem niezwykle ważnym dla kultury i imperializmu, i tworzy pomiędzy nimi jedno z głównych połączeń. A co najważniejsze, wielkie narracje emancypacyjne i oświeceniowe zmobilizowały skolonizowane ludy do zrywu wolnościowego i odrzucenia zależności od imperium ${ }^{43}$.

I tutaj także myślenie Saida wyrasta z klasycznego, by się tak wyrazić, kolonialnego kontekstu, którego manifestacją były tworzone i eksploatowane przez Anglię czy Francję pozaeuropejskie terytoria. Nie sądzę jednak, by schemat takiego myślenia o narracjach nie dał się przetransponować w kontekst relacji Europa Zachodnia - Europa Wschodnia. W takim kontekście romantyzm należy potraktować jako wielką narrację emancypacyjną, w której podejmuje się próby rehabilitacji zdeprecjonowanego dziedzictwa kulturowego. Narracje Zoriana Dołęgi Chodakowskiego czy Wacława Aleksandra Maciejowskiego należałoby potraktować jako przykłady snucia alternatywnych opowieści, legitymizujące "wypartą" tożsamość kulturową i religijną Słowian. Romantyczny bunt miał charakter kontrkulturowy (nie przez przypadek dwudziestowieczna kontrkultura obficie czerpała z romantycznej ideologii $\left.{ }^{44}\right)$, polegał na rehabilitacji tego, co zostało usunięte poza obręb kultury panującej.

${ }^{40}$ M. Janion, Niesamowita stowiańszczyzna, s. 165.

${ }^{41}$ E.W. Said, Orientalizm, przekł. M. Wyrwas-Wiśniewska, Poznań 2005, s. 35.

${ }^{42}$ E.W. Said, Kultura i imperializm, przekł. M. Wyrwas-Wiśniewska, Kraków 2009, s. X.

${ }^{43}$ Tamże, s. XI.

${ }_{44}$ Zob. T. Roszak, The Making of a Counter Culture. Reflections on the Technocratic Society $\mathcal{E}$ Its Youthful Oppositions, London 1973. 
Dzieje tradycji cyrylo-metodiańskiej opisywać można w kategoriach kulturowego oporu wobec łacińskiego chrześcijaństwa, co sugestywnie oddaje wyrażenie ukute przez Leonarda Górkę, piszącego o „słowiańskiej teologii wyzwolenia" w artykule poświęconym teologii głoszonej przez Braci Sołunskich. W takim ujęciu powiedzieć można, że Cyryl i Metody występowali w imieniu upośledzonych i pogardzanych Słowian:

(...) św. Cyryl wykorzystywał na swój misyjny użytek przekonanie o jedności wszystkich ludzi, o równorzędności praw każdego człowieka i równości ludów w ramach chrześcijańskiej rodziny narodów. W świetle tej idei Konstantyn-Cyryl dostrzegał wyraźniej niesprawiedliwość, a także fałsz w postawie pogardy i zniewolenia wobec ludzi, narodów słabszych, uboższych, pokrzywdzonych w procesie rozwojowym własnej kultury. Stąd też troska obu Braci Sołuńskich o wolność dla uwięzionych i niewolników, troska o prawo używania języka rodzimego w liturgii, dowartościowanie idei Kościołów lokalnych, czyli „siostrzanych”, stała się troską o fundamentalne prawa człowieka45.

Cyryl i Metody występowali przeciwko tzw. herezji trójjęzycznej, czyli ograniczaniu języka liturgii do trzech języków: hebrajskiego, greckiego i łacińskiego; broniąc prawa Słowian do uczestniczenia w obrzędach sprawowanych $\mathrm{w}$ ich języku występowali przeciwko relacjom dominacji wyrażanym poprzez język, ale i bronili prawa Słowian do tworzenia struktury kościelnej złożonej ze Słowian. Nie chodziło jednak tylko o język; przyswajanie tradycji cyrylo-metodiańskiej wykraczało poza spór o język liturgii. Jak pisze Leonard Górka, obrona słowiańskiej liturgii była obroną prawa wyboru „własnej drogi cywilizacyjnej” 46 . Wprowadzenie języka słowiańskiego (starosłowiańskiego) do liturgii umożliwiłoby rozwój kultury, którą współcześnie określilibyśmy mianem wysokiej, aparatu urzędniczego itp. Mając zapewne na myśli ten cywilizacyjny wymiar języka, Adolf Stender-Petersen twierdził, że „ogólnie zrozumiały język starosłowiański mógł się stać jednoczącą więzią polityczną i w ten sposób zagrozić cesarstwu niemieckiemu" ${ }^{\prime 7}$. W tej perspektywie lepiej widać dyskusyjną bezalternatywność podręcznikowej narracji o początkach państwa polskiego: być może istniała i alternatywna droga awansu cywilizacyjnego, nie przez łacinę i budowanie relacji opartych na zależności od zachodniego papiestwa, a szerzej - państw za-

${ }^{45}$ L. Górka SVD, Stowiańska teologia wyzwolenia na podstawie dzieła ewangelizacyjnego Patronów Europy, Cyryla i Metodego, [w:] Intelektualne i duchowe dziedzictwo Cyryla i Metodego. Historia i aktualność tradycji cyrylo-metodiańskiej, red. J. Budniak, A. Kasperek, Katowice 2014, s. 51.

46 Tamże, s. 53.

${ }^{47}$ M. Janion, Niesamowita stowiańszczyzna, s. 181. 
chodniego chrześcijaństwa. Podręcznikowy dyskurs podporządkowany jest jednak tezie dosadnie wyrażonej w Młodszej Europie Jerzego Kłoczowskiego:

"Zachód" będzie stale obecny [w książce Kłoczowskiego - A.K.] jako podstawowy punkt odniesienia, jako obszar, z którego wychodziły bodźce i modele różnie potem przyjmowane czy odrzucane ${ }^{48}$.

Taka okcydentalna perspektywa była bezkrytycznie podzielana przez autorów analizowanych podręczników oraz programów nauczania historii. Można ją określić mianem ewolucyjno-rewolucyjnej (spencerowsko-marksowskiej) i w wyrażeniu tym nie ma - jak sądzę - logicznej sprzeczności. Dyskurs ewolucyjny opiera się na pojęciu modernizacji, sprawiając wrażenie fałszywe, jak zauważa Peter Burke - że proces historyczny podporządkowany jest jednemu kierunkowi rozwoju, a zmiany przebiegać muszą jednotorowo ${ }^{49}$. Z drugiej strony, przyjęcie chrztu czy późniejsza reakcja pogańska noszą wszelkie znamiona gwałtownych wydarzeń o rewolucyjnym charakterze. Ewolucyjny model wyjaśnia zmiany odwołując się do endogennych czynników, zakłada konwergencję i jednotorowość rozwoju, pojęcie rozwoju staje się tutaj praktycznie synonimem postępu. Rewolucyjny model opiera się natomiast na przekonaniu o możliwości zaistnienia zmian także o egzogennym charakterze, zmian mających gwałtowny charakter. Na gruncie tego modelu dopuszcza się także możliwość regresu (vide reakcja pogańska). W perspektywie rozważań nad konstruowaniem pamięci historycznej warto więc zauważyć, że analiza podręczników daje podstawy do twierdzenia, że dominująca wśród autorów, będących zawodowymi historykami, narracja o początkach polskiej państwowości zostaje podporządkowana ewolucyjnorewolucyjnemu modelowi.

Zastosowana przez autorów podręczników argumentacja, język oraz symbolika, choć podkreślająca przełomowy (a zatem w znacznej mierze) rewolucyjny charakter zmian związanych z przyjęciem chrztu (semantyka przełomu), a zarazem w znacznej mierze pomijająca kwestię "pogańskiego" regresu, ma zasadniczo ewolucyjny charakter, odnoszący się także do relacji Wschód - Zachód. Świadczy o tym dyskurs w kategoriach postępu oraz stosowany przez autorów „dyskurs deprecjacji”. Powszechność tego mieszanego modelu, z przewagą ewolucyjnej perspektywy, trafnie oddaje wyrażenie będące zarazem tytułem książki Jerzego Kłoczowskiego: młodsza Europa, epitet odnoszący się do Europy Środkowo-Wschodniej. Młodsza,

48 J. Kłoczowski, Młodsza Europa. Europa Środkowo-Wschodnia w kręgu cywilizacji chrześcijańskiej średniowiecza, Warszawa 2003, s. 14.

${ }^{49}$ P. Burke, Historia i teoria spoteczna, s. 173. 
czyli jeszcze niedojrzała, w tym znaczeniu mniej doskonała niż starsza, zachodnia część Europy. Jeszcze raczkująca i z zazdrością spoglądająca na Zachód. W takiej optyce, wiernie powielanej przez autorów podręczników, bezalternatywność imitacji zachodniego modelu jest de facto równoznaczna z tezą historiozoficzną. Ceną uznania było przyjęcie reguł ustalanych przez silniejszego. Powtórzę zatem: ceną uznania była więc aprobata własnej niższości.

\section{Zakończenie}

Na koniec jeszcze jeden cytat z pracy Marii Janion:

Przeciwstawienie Zachodu i Wschodu dokonuje podziału jakości w następujący sposób: Zachód jest logiczny, normalny, empiryczny, kulturalny, racjonalny, realistyczny. Wschód zaś jest zacofany, zdegenerowany, niekulturalny, zapóźniony, skostniały, nielogiczny, despotyczny, nie uczestniczy twórczo w światowym postępie ${ }^{50}$.

Trudno taki Wschód traktować jako punkt odniesienia; w podobnej perspektywie $\mathrm{w}$ zasadzie trudno nie przyjąć historiozoficznego założenia, że rozwój możliwy jest wyłącznie przez zbliżanie się do Zachodu. Trudno jednak równocześnie $\mathrm{w}$ tym przeciwstawieniu nie dostrzec wzorcowego przykładu myślenia mitologicznego, opartego na odkrywaniu sensu historii. Mity tłumaczą rzeczywistość, opisują ją, a w końcu legitymizują, porządkują doświadczenie wprowadzając ład $\mathrm{w}$ biografię jednostkową, stanowią w końcu konstrukcję budującą uniwersum symboliczne.

Sądzę, że nie będzie nadinterpretacją postawienie tezy, że w przypadku analizowanych podręczników oraz programów spotykamy się ze zjawiskiem mitologizacji w dwojakim znaczeniu, o którym pisał Jerzy Topolski. Po pierwsze, istnieją w obszarze historiografii mity głębokie, ideologiczne oraz faktograficzne, przez które należy rozumieć nieświadomie przyjmowane przez historyków przedzałożenia badawcze. Według Topolskiego, przykładem mitu głębokiego są mity ewolucji i rewolucji; w tym drugim przypadku chodzi o „przesadne przeświadczenie o istnieniu $\mathrm{w}$ przeszłości pewnych faktów mających siłę łamania procesu historycznego" 51. Po drugie, Topolski pisze o mechanizmach mitologizacji, wśród których wymienia między innymi gloryfikacje postaci historycznych oraz „profetyzację", czyli przewidywanie "co do roli faktów historycznych w kształtowaniu przy-

${ }^{50}$ M. Janion, Niesamowita stowiańszczyzna, s. 224.

${ }^{51}$ Cyt. za: B. Szacka, Czas przeszty, pamięć, mit, s. 88. 
szłych losów ludzkości". O takiej gloryfikacji możemy mówić w przypadku postaci Mieszka I, natomiast jeśli chodzi o "profetyzację", to z takim zabiegiem spotykamy się $\mathrm{w}$ przypadku doszukiwania się $\mathrm{w}$ powstającej nowej mapie Europy z czasów Mieszka I antycypacji współczesnej wspólnoty państw europejskich skupionych $\mathrm{w}$ ramach struktur unijnych.

Autorzy podręczników i programów do historii marginalizują zarazem problematykę dominacji kulturowej uwikłaną w relację chrześcijaństwo słowiańszczyzna, chrześcijaństwo łacińskie i tradycja cyrylo-metodiańska, pomijają problematykę konfliktu (dialektyki) wpisaną w relacje między „starym" i „nowym". O perspektywie kulturowej dominacji (w tym także świadomości kulturowych przede wszystkim kosztów dominacji), która została praktycznie pominięta przez autorów podręczników Jan Assmann pisze następująco:

Kultura dominująca - formacja kulturowa dominującej etni - zyskuje wartość ponadetniczną i staje się kulturą wysoką i rozwiniętą (...) marginalizującą te kultury, na które się „nałożyła”. Powstanie wczesnych kultur wysoko rozwiniętych zbiega się zawsze $\mathrm{z}$ tworzeniem nowych form organizacji politycznej $(\ldots)^{52}$.

Trudno oprzeć się wrażeniu, że w analizowanych fragmentach zabrakło nie tylko świadomości uwikłania historycznej narracji w relację kultura dominująca - kontrkultura, ale i kluczowej świadomości, dobitnie wyrażonej przez Modzelewskiego, że chrzest „ludów barbarzyńskich” był zarazem "aktem burzenia" 53, a z kolei przyjęcie chrześcijaństwa w łacińskim obrządku było oczywiście politycznie i kulturowo uzasadnionym, jednak wcale nie tak oczywistym, aktem rezygnacji z prawa do wyboru alternatywnej drogi cywilizacyjnej. Słowiańszczyzna w dominującym kulturowym dyskursie nie wydaje się czymś atrakcyjnym i taki dyskurs (można go określić mianem dyskursu deprecjacji) organizuje podręcznikową narrację. Romantyczne odkrywanie słowiańszczyzny nie zagnieździło się pośród wiodących narracji historycznych; dziedzictwo to interpretowane jest niemal wyłącznie w kategoriach zapóźnienia, poczynając od organizacji politycznej, wyższości łaciny nad językiem starosłowiańskim, skończywszy - o czym pisał znawca mitologii Słowian Aleksander Gieysztor - na pozytywistycznych wyobrażeniach o "siermiężnych" bóstwach słowiańskich i prymitywizmie słowiań-

52 J. Assmann, Pamięć kulturowa. Pismo, zapamiętywanie i polityczna tożsamość w cywilizacjach starożytnych, przekł. A. Kryczyńska-Pham, Warszawa 2008, s. 159.

${ }^{53}$ K. Modzelewski, Barbarzyńska Europa, s. 455. 
skich wierzeń54. Autor Mitologii Słowian opisuje zarazem fascynującą słowiańską wizję świata, którego kres wyznaczała chrześcijańska ekspansja (oczywiście z tezą, że jego ślady przetrwały w kulturze ludowej). Efektem zapomnienia, swoistego wyparcia, ale i lekceważenia jest pewna konsternacja, której doświadczają moi studenci, kiedy proszę ich o wymienienie imion słowiańskich bogów. Języki studentów rozwiązują się, gdy przechodzimy do greckiego panteonu bogów.

\section{BIBLIOGRAFIA}

Assmann J., Pamięć kulturowa. Pismo, zapamiętywanie i polityczna tożsamość w cywilizacjach starożytnych, przekł. A. Kryczyńska-Pham, Wydawnictwa Uniwersytetu Warszawskiego, Warszawa 2008.

Banaszczyk T., Durkheim i protagoniści, Polska Akademia Nauk - Oddział w Katowicach, Wydawnictwo Gnome, Katowice 1996.

Bloch M., Pochwata historii czyli o zawodzie historyka, przekł. W. Jedlicka, Państwowe Wydawnictwo Naukowe, Warszawa 1960.

Braudel F., Historia i trwanie, przekł. B. Geremek, Czytelnik, Warszawa 1971.

Burke P., Historia i teoria społeczna, przekł. M. Łamacz, Wydawnictwo Naukowe PWN, Warszawa - Kraków 2000.

Czyżewski M., Wprowadzenie, [w:] Rytualny chaos. Studium dyskursu publicznego, red. M. Czyżewski, S. Kowalski, A. Piotrowski, Wydawnictwo Aureus, Kraków 1997.

Dołęga Chodakowski Z., O Stawiańszczyźnie przed chrześcijaństwem, [w:] Z. Dołęga Chodakowski, O Stawiańszczyźnie przed chrześcijaństwem oraz inne pisma $i$ listy, oprac. J. Maślanka, Państwowe Wydawnictwo Naukowe, Warszawa 1967.

Górka L. SVD, Stowiańska teologia wyzwolenia na podstawie dzieła ewangelizacyjnego Patronów Europy, Cyryla i Metodego, [w:] Intelektualne i duchowe dziedzictwo Cyryla i Metodego. Historia $i$ aktualność tradycji cyrylo-metodiańskiej, red. J. Budniak, A. Kasperek, Polska Akademia Nauk - Oddział w Katowicach, Studio Noa, Katowice 2014.

Gurvitch G., La multiplicité des temps sociaux, [w:] G. Gurvitch, La vocation actuelle de la sociologie. Antécédents et perspectives, t. II, Presses Universitaires de France, Paris 1969.

Honneth A., La société du mépris. Vers une nouvelle Théorie critique, trad. O. Voirol, P. Rusch, A. Dupeyrix, Éditions La Découverte, Paris 2006.

Janion M., Niesamowita Słowiańszczyzna: fantazmaty literatury, Wydawnictwo Literackie, Kraków 2006.

Kasperek A., Cabała A., The Forgotten Slavism. A Sociological Study on the Depreciation of the Memory Concerning the Slavic Heritage in History Textbooks and Curricula in Secondary Schools, Kultura i Edukacja, 2013, 5(98).

Kłoczowski J., Młodsza Europa. Europa Środkowo-Wschodnia w kręgu cywilizacji chrześcijańskiej średniowiecza, Państwowy Instytut Wydawniczy, Warszawa 2003.

Modzelewski K., Barbarzyńska Europa, Wydawnictwo Iskry, Warszawa 2004.

${ }^{54}$ L.P. Słupecki, Postowie, [w:] A. Gieysztor, Mitologia Stowian, oprac. A. Pieniądz, Warszawa 2006, s. 324-325. 
Nora P., Between Memory and History: Les Lieux de Mémoire, Representations, 1989, 26.

Nowak J., Społeczne reguty pamiętania. Antropologia pamięci zbiorowej, Zakład Wydawniczy Nomos, Kraków 2011.

Pereyra C. i in., Po co nam historia? przekł. M. Mróz, Państwowy Instytut Wydawniczy, Warszawa 1985.

Roszak T., The Making of a Counter Culture. Reflections on the Technocratic Society \& Its Youthful Oppositions, Faber and Faber, London 1973.

Said E.W., Orientalizm, przekł. M. Wyrwas-Wiśniewska, Zysk i S-ka Wydawnictwo, Poznań 2005.

Said E.W., Kultura i imperializm, przekł. M. Wyrwas-Wiśniewska, Wydawnictwo Uniwersytetu Jagiellońskiego, Kraków 2009.

Słupecki L.P., Posłowie, [w:] A. Gieysztor, Mitologia Słowian, oprac. A. Pieniądz, Wydawnictwa Uniwersytetu Warszawskiego, Warszawa 2006.

Szacka B., Czas przeszły, pamięć, mit, Instytut Studiów Politycznych PAN, Wydawnictwo Naukowe Scholar, Warszawa 2006.

Szpociński A., Formy przeszłości a komunikacja społeczna, [w:] A. Szpociński, P.T. Kwiatkowski, Przeszłość jako przedmiot przekazu, Instytut Studiów Politycznych PAN, Wydawnictwo Naukowe Scholar, Warszawa 2006.

Szpociński A., Przemiany obrazu przeszłości Polski. Analiza stuchowisk historycznych dla szkót podstawowych 1951 - 1984, Uniwersytet Warszawski, Instytut Socjologii, Warszawa 1989.

Traba R., Historia - przestrzeń dialogu, Instytut Studiów Politycznych PAN, Warszawa 2006.

Villoro L., O sensie istnienia historii, przekł. M. Mróz, [w:] Po co nam historia, Państwowy Instytut Wydawniczy, Warszawa 1985. 